\title{
SIMULASI ANTRIAN PELAYANAN BANK MENGGUNAKAN METODE EKSPONENSIAL
}

\author{
Andika $^{1)}$, Akim Manaor Hara pardede ${ }^{2)}$, Novriyenni ${ }^{3)}$ \\ STIMIK KAPUTAMA \\ ${ }^{1,3}$ Prodi TeknikInformatika, ${ }^{2}$ Prodi SistemInformasi \\ Jl. Veteran No. 4A-9A, Binjai, Sumatera Utara, 20714,Indonesia \\ andikarokets@gmail.com ${ }^{1)}$ akimmhp@live.com ${ }^{2}$,novri_yenni@yahoo.com ${ }^{3)}$
}

\begin{abstract}
ABSTRAK
Zaman modern saat ini menuntut semuanya harus cepat dan tepat. Ini karena semakin bertambahnya populasi di dunia saat ini yang terus bertambah. Antrian adalah suatu aktifitas di mana pelanggan menunggu untuk mendapatkan layanan. Dalam sistem antrian terkadang mengalami masalah, masalah muncul karena banyaknya antrean di layani. Antrean panjang terjadi karena banyaknya transaksi di kasir baik transfer, tarik tunai, pembayaran hipotek, dana pensiun mengambil dan menerima retensi kas. Model antrian yang dibahas dalam penelitian ini adalah antrian dimana pelanggan datang berkelompok. Jumlah pelanggan dalam setiap kelompok adalah variabel acak, dan waktu antara kedatangan distribusi eksponensial. Pada penelitian metode Exponential digunakan untuk menghitung waktu layanan dengan saluran tunggal untuk dapat mengamati bagaimana kinerja sistem. Berdasarkan hasil penelitian, diperoleh server yang cukup untuk melayani adalah sebanyak 3 server, jika hanya 1 server akan menghasilkan waktu tunggu rata-rata yang terlalu lama sehingga pelanggan akan bosan menunggu beberapa saat jika Anda menggunakan 4 server akan menghasilkan waktu menunggu rata-rata sangat sedikit sampai server kosong
\end{abstract}

Kata kunci: Antrean, Eksponensial, Simulasi

ABSTRACT

In modern times currently demanded everything must be quick and precise. This is because the more the increase of population in the world today that keeps growing. The queue is a aktifiitas where customers wait to obtain a service. In the system queue sometimes experiencing a problem, the problem arises because the number of queued on the serve. A long queue occurs because of the large number of transactions at the teller either transfers, cash with drawals, mortgage payments, retirement funds are taking and receive cash retention. Queueing models discussed in this research is a queue where customers come in groups. The number of customers in each group is a random variable, and the time between the arrival of the exponential distribution is. On the research of Exponential method is used to calculate the time of service with a single channel to be able to observe how the performance of the system. Based on research results, gained sufficient servers to serve is as much as 3 servers, if only 1 server will result in average waiting times are too long resulting in the customer will get tired of waiting for a while if you're using 4 the server will result inan average waiting time of very little until the server is idle

Keywords: Queue, Exponential, Simulation 


\section{PENDAHULUAN}

Pada zaman modern saat ini dituntut segala sesuatu harus cepat dan tepat. Hal ini dikarenakan semakin bertambahnya jumlah populasi penduduk di dunia saat ini yang terus bertambah. Perkembangan teknologi dan pembangunan juga meningkat sangat pesat, tentunya hal tersebut mempengaruhi pola hidup di masyarakat.Sebuah perusahaan mulai dari bidang jasa maupun manufaktur juga harus mampu memberikan pelayanan yang sangat cepat serta yang terbaik untuk memenuhi keinginan dari masyarakat yang memerlukan pelayanan yang cepat.

Dalam hal memberikan pelayanan tidak lengkap jika tidak menyebut bank, dalam bank sering kita jumpai pelayanan dan antrian. Antrian merupakan sebuah aktifiitas dimana pelanggan menunggu untuk memperoleh sebuah layanan. Dimana dengan adanya suatu antrian proses dalam sebuah kegiatan menjadi lebih teratur. Antrian sering kita jumpai di sekitar kita seperti pada saat seseorang akan mengantri untuk membeli atau membayar sesuatu, namun masih banyak antrian yang terjadi di lingkungan masyarakat selain di bank, seperti antrian untuk membeli tiket kereta api, membeli tiket di wahana rekreasi taman bermain, antrian barang dalam kantor pos dan masih banyak lagi antrian yang terjadi dalam kehidupan sehari-hari.

Dalam sistem antrian terkadang mengalami suatu masalah, masalah timbul karena banyaknya yang mengantri dari pada yang melayani. Antrian yang panjang terjadi karena banyaknya transaksi pada teller baik transaksi transfer, Tarik tunai, pembayaran cicilan, pengambilan dana pensiunan dan menerima penyimpanan uang tunai. Masalah tersebut sering terjadi dan tentunya membuat masyarakat menjadi bosan dan tentunya membuat masyarakat menjadi malas mengantri.

Penelitian ini diilhami oleh penelitian sebelumnya yang berjudul "Simulasi Antrian Kedatangan berkelompok dengan Pelayanan Weibull Oleh Banyak Server" (Pardede, Akim M.H., Jurnal Teknologi Informasi dan Komunikasi \Vol. 3 No. 1 Juni
2014, BBPPKI) [1] dari hasil referensi tersebut menghasilkan salah satu kesimpulan yaitu Hasil simulasi Weibull, $\mathrm{K}=200, \lambda=2$, $\mu=20$ dengan durasi 1-6 jam, jika di layani dengan 10 server maka rata-rata server sibuk (utility server) 0,9657 dan durasi waktu yang diberikan untuk melayani tidak mencakupi, jika dilayani dengan 20 server maka rata-rata utility server 0,6402 sangat memadai kebutuhan, dan jika server yang digunakan 30 maka rata-rata utility server 0,4460 dapat mengakitbatkan server menganggur karena pelanggan yang sedikit.

Pada peneliian sebelumnya menggunakan metode Hyperexponential, menghasilkan kesimpulan jumlah server terbaik pada suatu bank studi kasus yang dibhasa adalah dengaan menggunakan 3 server, dengan jumlahnasabah dalam durasi 5 jam adalah 48, probabilitas server sibuk (utility server) $51.53 \%$, rata-rata waktu tunggu $(\mathrm{Wq}) 0$ menit 32 detik, rata-rata waktu tunggu dalam sistem (Ws) 10 menit 11 detik, dan rata-rata jumlah pelanggan.dalam sistem (Lq) 0.0842 , rata-ratajumlah pelanggan dalam antrian (Ls)1.6302 dan service berakhir pada5:07:59 (Pardede, AMH. 2018) [2] .

Berdasarkan latarbelakang di atas, maka yang menjadi rumusan permasalahan adalah :

1. Dengan menggunakan metode eksponensial, Bagaimana cara menerapkan simulasi antrian pelayanan nasabah di Bank Syariah Mandiri?

2. Dengan VB.NET 2010, Bagaimana cara membangun sistem simulasi antrian pelayanan nasabah di Bank Syariah Mandiri?

Manfaat yang di peroleh dari hasil penelitian ini adalah :

1. Dengan membuat simulasi sistem antrian diharapkan sistem pelayanan pada Bank lebih baik lagi.

2. Dengan adanya simulasi ini di harapkan menjadi acuan Bank agar lebih efektif dan efisien dan memberikan pelayanan yang lebih maksimal lagi.

\section{Pengertian Perancangan}

Merancang merupakan hal yang harus pertama kali dilakukan saat membuat atau 
menciptakan hal baru, dan dengan merancang hal tersebut tentunya memudahkan seseorang untuk mengerjakan pekerjaan mereka tentunya.

Definisi perancangan menurut Al-Bahra Aljamudin (2013) [3] dalam bukunya yang berjudul analisis dan desain sistem informasi yaitu : Tahapan perancangan (design) memiliki tujuan untuk mendesain sistem baru yang dapat menyelesaikan masalah-masalah yang dihadapi perusahaan yang diperoleh dari pemilihan alternative sistem yang terbaik.

\section{Pengertian Simulasi}

Kata simulasi berasal dari bahasa asing (Inggris) yaitu to simulate yang berarti menirukan, sedang kata simulation yang diterjemahkan ke bahasa Indonesia dengan simulasi mempunyai makna tiruan atau upaya menirukan, yaitu menirukan suatu sistem nyata (real system) yang menjadi obyek kajian dalam rangka mencari jawaban atas persoalan sistem tersebut.

\section{Sistem Antrian}

Teori antrian berhubungan dengan semua aspek dari situasi dimana pelanggan harus menunggu untuk diberikan layanan, lama dalam pelayanan hingga selesai semua layanan, semua situasi ini merupakan bagian dari antrian selama pelanggan mulai masuk kedalam sistem antrian (Simamora, R.J., 2010) [4].

Sistem antrian adalah merupakan keseluruhan dari proses para pelanggan atau barang yang berdatangan dan memasuki barisan antrian yang seterusnya memerlukan pelayanan sebagaimana seharusnya berlaku. Dalam mempelajari suatu sistem antrian, perlu untuk diketahui struktur sistem antrian, yaitu unit yang memerlukan pelayanan disebut pelanggan (customer) dan yang melayani disebut pelayan (server). (Pardede, 2014, h.2)[1].

\section{Struktur Sistem Antrian}

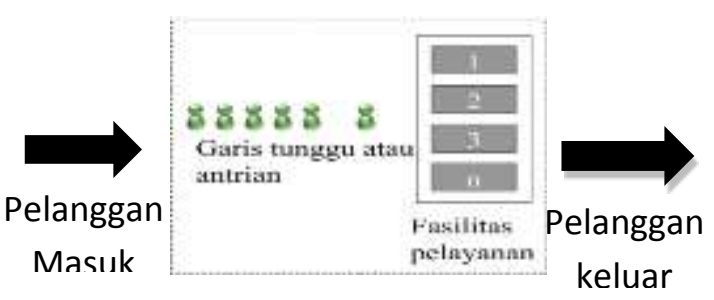

Gambar 1. Struktur Sistem Antrian

\section{KomponenAntrian}

3 (tiga) komponen utama dalam teori antrian yang harus benar-benar diketahui dan dipahami (Pardede, 2013, h.5)[5],yaitu:
a. Tingkat kedatangan
b. Tingkat pelayanan
c. Disiplin antrian

\section{FaktorSistemAntrian}

Faktor-faktor yang berpengaruh terhadap barisan antrian dan pelayanannya adalah sebagai berikut (Pardede, 2013, h.7-8) [5] :

1. Distribusi Kedatangan

Pada sistem antrian, distribusi kedatangan merupakan faktor penting yang berpengaruh besarterhadap kelancaran pelayanan.

Distribusi kedatangan terbagi dua,yaitu :

a. Kedatangan secaraindividu (tunggal =singlearrivals)

b. Kedatangan secaraberkelompok (bulkarrivals)

Kedua komponen ini harus mendapatkan perhatian yang memadai pada saat pendisainan sistem pelayanan.

2. Distribusi Waktu Pelayanan

Distribusi waktu pelayanan berkaitan dengan berapa banyak fasilitas pelayanan yang dapat disediakan. Distribusi waktu pelayanan terbagi menjadi dua komponen penting,yaitu :
a. Pelayanan secara individual (singleservice)
b. Pelayanan secara kelompok (bulkservice)

3. Fasilitas pelayanan

Fasilitas pelayanan berkaitan erat dengan baris antrian yang akan dibentuk. Desain fasilitas pelayanan ini dapat dibagi dalam tiga bentuk,yaitu : 
a. Bentuk series, dalam satu garis lurus ataupun garis melingkar.

b. Bentuk paralel, dalam bebebera pagaris lurus yang antara satu dengan yang lain parallel.

4. Bentuk networ kstation, yang dapat didesain secaras eries dengan pelayanan lebih dari satu pada setiap stasiun. Bentuk ini dapat juga dilakukan secara paralel dengan stasiun yang berbedabeda. Dengan demikianbentuk fasilitas pelayanan ini juga harus diperhitungkan dalam sistem antrian.

5. Disiplin pelayanan

Disiplin pelayanan berkaitan erat dengan urutan pelayanan bagi pelanggan yang memasuki fasilitas pelayanan.

6. Ukuran dalam antrian

Besarnya antrian pelanggan yang akan memasuki fasilitas pelayanan pun perlu diperhatikan. Ada dua desain yang dapat dipilih untuk menentukan besarnya antrian,yaitu :

a. Ukuran kedatangan secara tidak terbatas (infinitequeue)

b. Ukuran kedatangan secara terbatas (finite queue)

7. Sumber pemanggilan

Dalam fasilitas pelayanan, yang berperan sebagai sumber pemanggilan dapat berupa mesin maupun manusia. Bila ada sejumlah mesin yang rusak maka sumber pemanggilan akan berkurang dantidak dapat melayani pelanggan. Jadi masalahnya adalah apakah :

a. Sumber panggilan terbatas (finite calling source)

Sumber panggilan takterbatas (infinite calling source)

\section{Distribusi Poison}

Suatu distribusi mengikuti pola distribusi poisson jika mengikuti aturan berikut ini:

a. Tidak terdapat dua kejadian yang terjadi bersamaan.

b. Proses kedatangan bersifat acak. c. Rata-rata jumlah kedatangan per interval waktu sudah diketahui dari pengamatan sebelumnya.

d. Bila interval waktu dibagi kedalam interval yang lebih kecil, maka pernyataan-pernyatan berikut ini harus dipenuhi:

a) Probabilitas tepat satu kedatangan adalah sangat kecil dan konstan.

b) Probabilitas dua kedatangan atau lebih selama interval waktu tersebut angkanya sangat kecil sehingga mendekati nol.

c) Jumlah kedatangan pada interval waktu tersebut tidak tergantung pada kedatangan di interval waktusebelumdansesudahnya.

Berikut ini merupakan probability mass function dari distribusi poisson:

$$
P(x)=\frac{\lambda^{x}}{x !} e^{-\lambda}, x=0,1,2, \ldots ., \lambda>0
$$

\section{Distribusi Eksponensial}

Distribusi probabilitas eksponensial merupakan pengujian digunakan untuk melakukan perkiraan atau prediksi dengan hanya membutuhkan perkiraan rata -rata populasi,karena dalam distribusi eksponensial memiliki standar deviasi sama dengan ratarata. Distribusi ini termasuk ke dalam distribusi kontinyu. Ciri dari distribusi ini adalah kurvanya mempunyai ekor di sebelah kanan dan nilai $\mathrm{x}$ dimulai dari 0 sampai tak hingga.

Gambar kurva distribusi eksponensial berbeda-beda tergantung dari nilai $\mathrm{x}$ dan $\lambda$. 


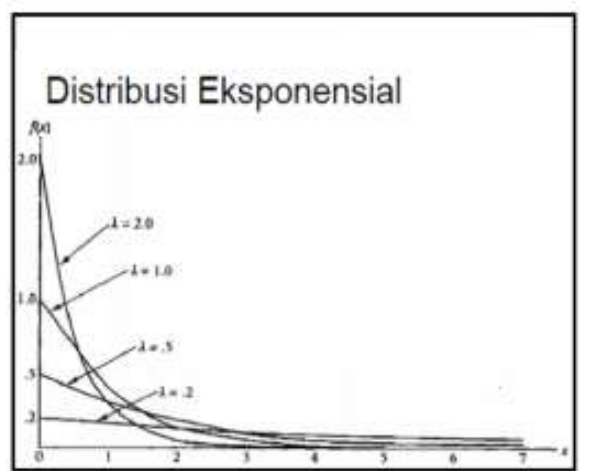

Gambar 2. Kurva Distribusi Eksponensial Syarat dari distribusi eksponensial yaitu :

- $X=0$

- $\lambda>0$

- $\mathrm{e}=2,71828 \ldots$

Dimana :

- $\mathrm{x}=$ interval rata-rata

- $\lambda=$ parameter rata-rata

- $\mathrm{Xo}=$ rata-rata sampel

- $e \quad=$ eksponensial $=2,71828 \ldots$

Distribusi ini digunakan untuk menghitung waktu antar kedatangan dan waktu pelayanan setiap pelanggan atau pembeli yang dilayani oleh server. Alasan pemilihan distribusi Eksponensial karena distribusi ini lebih mendekati pendekatan yang lebih konstan jika dibandingkan dengan distribusi normal.

Waktu pelayanan adalah waktu yang dihabiskan seorang pelanggan pada fasilitas pelayanan. Waktu pelayanan antar seorang pelanggan dengan pelanggan lainnya biasanya tidak konstan. Distribusi probabilitas untuk waktu pelayanan biasanya mengikuti distribusi probabilitas eksponensial yang formula dapat memberikan informasi yang berguna mengenai operasi yang terjadi pada suatu antrian. Sifat dari distribusi eksponensial yang membuat distribusi tersebut mudah untuk dianalisis adalah bahwa distribusi ini tidak tergantung pada waktu (memory less proferty atau sifat pelupa).formula untuk distribusi eksponensial adala sebagai berikut (Pardede, 2013, h.12) [5].

Dimana

$$
F(t)=\mu \cdot e^{-\mu t}, t \geq 0(2)
$$

$\mu=$ Jumlah pelanggan rata-rata yang dilayani pada periode waktu tertentu

$\mathrm{t}=$ waktu pelayanan

$\mathrm{e}=2,71828$ (Logika natural)

Untuk mendefinisikan model suatu sistem antrian dan merincikan ciri dari suatu sistem antrian digunakan notasi kendall a/b/c/d/e/f (Pardede, 2013,h.15), yang artinya adalah:

a. distribusi kedatangan (Arrival Distribution)

b. distribusi waktu pelayanan / keberangkatan (Service Time Departure)

c. jumlah fasilitas pelayanan parallel (dimana $\mathrm{c}=1,2,3 \ldots \infty)$

d. disiplin pelayanan (FIFO,LCFS, SIRO)

e. jumlah maksimum yang diizinkan dalam sistem (Queue and System)

f. jumlah pelanggan yang ingin memasuki sistem sebagai sumber.

Untuk distribusi kedatangan pelanggan (a) dan distribusi waktu pelayanan pelanggan (b) yang sering digunakan di dalam suatu sistem antrian, yaitu :

M : Distribusi Markovian, Poisson, Eksponensial, atau Memoryless

G : Distribusi General, Gamma, Weibull, dll

GI : Distribusi General Independel

D : Distribusi Deterministic

$\mathrm{E}_{\mathrm{k}} \quad$ : Distribusi Erlang-k atauGamma-k

$\mathrm{H}_{\mathrm{k}}$ : Distribusi Hyperexponensial-k

$\mathrm{C}_{\mathrm{k}}$ : Distribusi Cox-k

\section{Bilangan Acak}

$\mathrm{PH}_{\mathrm{k}}$ : Distribusi Phase type at k stages

Menurut Pardede (2013, h.18)[5], untuk menentukan input probabilistic, dibangkitakan bilangan acak yang sesuai dengan distribusi kejadian yang akan disimulasikan.

a. Bilangan Acak Distribusi Eksponensial Untuk membangkitkan suatu bilangan acak yang berdistribusi Eksponensial dapat diperoleh algoritma dengan metode inverse transformation sebagai berikut (Pardede (2013, h.18)[5].

1. Bangkitkan $\mathrm{U}=\mathrm{U}(0,1)$ 
2. Hitung $\chi=-\frac{1}{\mu} \ln (\mathrm{U})$

b. Bilangan Acak Distribusi Weibull Untuk membangkitkan suatu bilangan acak yang berdistribusi Weibull dapat diperoleh dengan metode inverse transformation (Pardede (2013, h.18)).

1. Bangkitkan $\mathrm{U}=\mathrm{U}(0,1)$
2. Hitung $\chi=\frac{1}{\mu}(-\ln (\mathrm{U}))$

\section{METODE PENELITIAN}

Adapun teknik pengumpulan data yang digunakan dalam penelitian ini adalah :

1. Studi Pustaka, penelitian ini dilakukan dengan cara pemahaman terhadap literature yang berupa buku - buku wajib, catatan perkuliahan yang berhubungan dengan Teori Antrian.

2. Penelitian Lapangan berupa pengamatan, yaitu peneliti melakukan berbagai pengamatan mengenai proses antrian pelayanan pada Bank Syariah Mandiri, peneliti mengamati bagaimana antrian terjadi, waktu antrian dan lama pelayanan pada antrian tersebut.

\section{Rancangan Penelitian}

Pada penelitian ini peneliti membahas mengenai antrian dimana kedatangan nasabah secara tunggal mengikuti proses Poisson yang memiliki single Teller atau antrian tunggal dan single queue atau satu antrian dengan aturan FIFO. Nasabah yang datang lebih dulu akan dilayani sampai semua nasabah yang ada dalam kelompok itu selesai dilayani baru kemudian Teller memulai pelayanan terhadap nasabah yang datang berikutnya.

Nasabah yang datang akan dilayani oleh Teller, dimana urutan pelayanan terhadap nasabah yang berada dalam satu antrian sesuai dengan waktu kedatangan nasabah. Apabila Teller dalam keadaan menganggur, maka salah satu nasabah dalam antrian akan langsung di layani. Waktu antar kedatangan nasabah berdistribusi Poisson, waktu pelayanan berdistribusi Eksponensial.

Pada umumnya untuk membentuk model matematis dari suatu keadaan nyata sehari-hari diperlukan asumsi-asumsi untuk menyederhanakan model, sehingga dapat diselesaikan dengan simulasi computer dengan baik. Adapun Natasi-notasi yang akan digunakan adalah sebagai berikut :

$$
\begin{array}{cl}
\lambda & : \text { Laju Kedatangan } \\
\mu & : \text { Laju pelayanan } \\
\mathrm{C} & : \text { Teller } \\
\rho & : \text { Probabilitas Teller sibuk } \\
\mathrm{L}_{\mathrm{s}} & : \text { Rata-rata nasabah dalam sistem } \\
\mathrm{L}_{\mathrm{q}} & : \text { Rata-rata nasabah dalam antrian } \\
\mathrm{W}_{\mathrm{s}} & : \text { Rata-rata waktu tunggu dalam sistem } \\
\mathrm{W}_{\mathrm{q}} & : \text { Rata-rata waktu tunggu dalam }
\end{array}
$$
antrian

Sedangkan untuk performansi sistem antrian dapat dicari dengan rumus sebagai berikut:

a. Waktu tunggu nasabah dalam antrian

= Waktu dimulai pelayanan - waktu kedatangan nasabah

b. Waktu tunggu nasabah dalam sistem

$=$ Waktu selesai pelayanan - waktu kedatangan nasabah

c. Rata-rata waktu tunggu dalam antrian (Wq) $\mathrm{Wq}=\sum \frac{\text { waktu tunggu pelanggan dalam antrian }}{\text { total pelanggan }}$

(7)

d. Rata-rata waktu tunggu dalam sistem (Ws)

$\underline{\sum \text { Waktu tunggu pelanggan dalam sistem }}$

Total Pelanggan

(8)

e. Rata-rata nasabah dalam antrian (Lq) $\left[\frac{\sum \text { Waktutunggu pelanggan dalam antrian }}{\text { Durasi }}\right]$

(9)

f. Rata-rata nasabah dalam sistem (Ls)

$\frac{\sum \text { Waktutunggu pelanggan dalam sistem }}{\text { Durasi }}$

(10)

g. Probabilitas Teller sibuk $(\rho)$

$\frac{\sum \text { Waktu pelayanan }}{\text { Banyak server } * \text { Durasi }}$

(11) 


\section{Flowchart Kedatangan}

Proses kedatangan merupakan suatu proses untuk membangkitkan kedatangan nasabah. Waktu antar kedatangan nasabah adalah acak (random). Pada proses kedatangan dilakukan input parameter, yaitu laju kedatangan, laju pelayanan, dan durasi simulasi. Hasil proses ini adalah menentukan seberapa banyak kedatangan, membangkitkan bilangan acak waktu antar kedatangan dan untuk menentukan waktu kedatangan selama durasi simulasi.

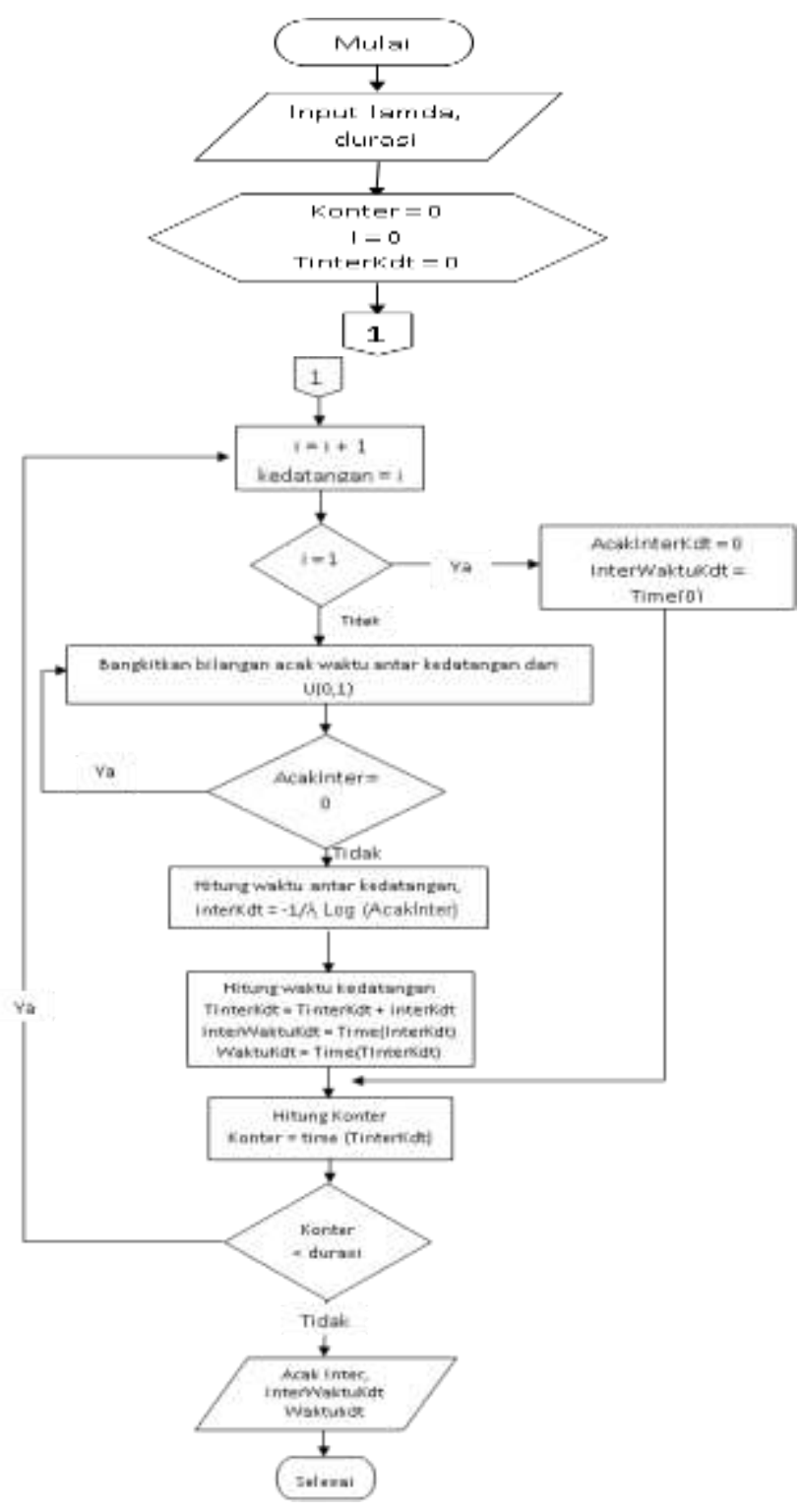

Gambar 3. Flowchart kedatangan
Penjelasan Flowchart kedatangan

1. Pertama, mulai

2. Lalu input nilai lamda dan durasi

3. Selanjutnya, nilai awal konter $=0, \mathrm{i}=0$, TinterKdt $=0$

4. $\mathrm{i}+1$ dimana $\mathrm{i}=$ kedatangan

5. Selanjutnya, masukke decision, apakah nilai $\mathrm{i}=1$ ? Jika ya maka ke proses acakinterkdt $=0$, interwaktukdt $=0$

6. Lalu, proses menghitung konter, konter $=$ Tinterkdt

7. Selanjutnya, apakah konter lebih kecil dari durasi? Jika ya lanjut ke kedatangan ke 2

8. Karena nilai i tidak sama dengan 1 maka, bangkitkan bilangan acak

9. Jika bilangan acak masih 0 , kita bangkitkan lagi

10.Jika tidak, masuk ke proses menghitung interkdt, yaitu negative $1 /$ lamda $* \log$ (acakinter)

11.Lalu, hitung Tinterkdt, interwaktukdt, waktukdt,

12.Proses tersebut akan berulang, hingga nilai konter tidak lebih kecil dari durasi

13.Lalu hasil, acakinter, interwaktukdt, waktukdt

14.Selesai

\section{Flowchart Pelayanan}

Proses pelayanan merupakan suatu proses dimana pelanggan mulai dilayani sampai dengan selesainya pelayanan yang diberikan kepada pelanggan dan

meninggalkan sistem. Pada proses ini waktu pelayanan yang diberikan kepada pelanggan adalah bilangan acak. Di proses ini juga dihitung waktu tunggu pelanggan didalam antrian, waktu tunggu pelanggan di dalam sistem dan total waktu pelanggan dalam sistem. Kemudian untuk pelayanan selanjutnya ditentukan kapan mulainya pelayanan dengan melihat waktu kedatangannya di sistem selesainya pelayanan sebelumnya 


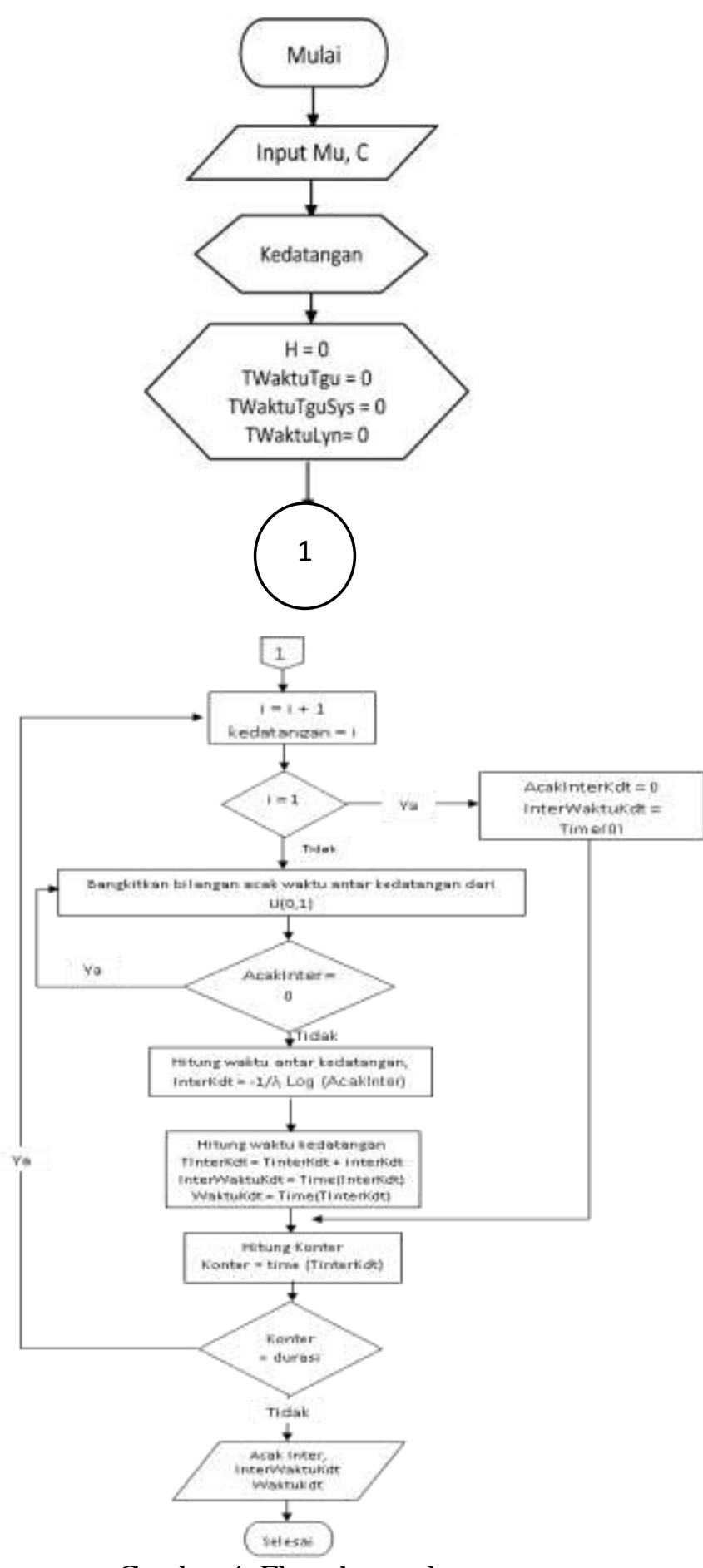

Gambar 4. Flowchart pelayanan

Penjelasan FlowChart Pelayanan

1. Mulai

2. Input Nilai Mu dan c (Server)

3. Ambil nilai dari kedatangan
4. Nilai awal $\mathrm{h}=0$, Twaktutgu, Twaktutgusys, Twaktulyn

5. Lalu, nasabah $=h$, dimana $h=h+1$

6. Jika h lebih kecil sama dengan c, jika ya, proses hitung server dimana server $=\mathrm{h}$

7. Karena masih kedatangan pertama, jadi mulailyn = waktudtg

8. Bangkitkan acaklyn dengan rand()

9. Hitung layan $=$ negative $1 / \mathrm{mu} * \log$ (acaklyn)

10.Lalu hitung selesailyn. Waktutgu, dan waktusys

11.Jika nasabah (h) lebih kecil sama dengan kedatangan, maka $h=2$, sampai nilai $h$ tidak lebih kecil dari c,

12.Lanjut ke hitung server, dimana server $=$ server dengan waktu selesai terkecil,

13.Selanjutnya, jika waktu datang lebih kecil sama dengan waktu selesai h - 1, jika ya, mulailyn $=$ waktudtg, jika tidak mulailyn $=$ selesailyn server

14.Lanjut seperti sebelumnya, membangkitkan bilangan acak

15.Lalu menghitung proses perhitungan waktu pelayanan

16.Hitung waktu selesai pelayanan, waktu tunggu, waktu tunggu sistem.

17.Apakah nilai $\mathrm{H}$ lebih kecil sama dengan kedatangan, jika ya, hitung kedatangan selanjutnya.

18.Lalu proses akan terus berulang sampai $h$ tidak lebih kecil dari kedatangan,

19. Barulah menghitung waktukdt, mulailyn, waktulyn, selesailyn, wktutgu, waktutgusys, p, wq, ws, lq, ls

20.Selesai

\section{HASIL DAN PEMBAHASAN} Implementasi Metode Eksponensial pada Simulasi Antrian

1. Kedatangan

Untuk membangkitkan kedatangan digunakan distribusi Poisson dengan pembangkit bilangan acak : $-\frac{1}{\lambda} \cdot \log (U)$, 
misalnya $\lambda=5$ dengan durasi $=1$ jam $(60$ menit).

\section{Kedatangan 1 :}

Acak

Interval waktu kedatangan $\quad=0$

Waktu kedatangan $\quad=0$

Kedatangan 2 :

Bangkitkan $U=U(0,1) \quad=0,7154$

- Interval waktu kedatangan $=$

$$
-\frac{1}{5} \cdot \log (0,7154)=0,0291
$$

$$
\begin{array}{ll}
\mathrm{x} & =\text { Interval waktu kedatangan } * \\
3600 & =105 \\
\text { Menit } & =\mathrm{x} / 60=1.74=1 \text { menit } \\
\text { Detik } & =\mathrm{x} \text { mod } 60=45=45 \text { detik }
\end{array}
$$

- Waktu kedatangan $=0+0,0291=$ 0,0291

$$
\mathrm{x}=\text { Waktu kedatangan } * 3600=
$$
105

Menit $=\mathrm{x} / 60=1.74=1$ menit

Detik $=\mathrm{x} \bmod 60=45=45$ detik

Untuk menit berlaku pembulatan ke bawah, sisa desimal masuk ke detik.

Demikian dengan kedatangan ke- $n$ dihitung dengan rumus yang sama.

Konter $=$ Total interval waktu kedatangan,

Jika konter $\geq$ durasi maka selesai, jika konter $<$ durasi maka bangkitkan kedatangan berikutnya.

\section{Tabel 1. Kedatangan}

\begin{tabular}{|c|c|c|c|}
\hline Kedatangan & $\begin{array}{c}\text { Acak } \\
\text { Rand() }\end{array}$ & $\begin{array}{c}\text { Interval Waktu } \\
\text { Kedatangan }\end{array}$ & $\begin{array}{c}\text { Waktu } \\
\text { kedatangan }\end{array}$ \\
\hline 1 & 0 & 0 & 0 \\
\hline 2 & 0.7154 & 0.0291 & 0.0291 \\
\hline 3 & 0.4240 & 0.0745 & 0.1036 \\
\hline 4 & 0.3929 & 0.0811 & 0.1848 \\
\hline 5 & 0.4750 & 0.0647 & 0.2494 \\
\hline
\end{tabular}

Tabel di atas menunjukan bahwa hasil dari simulasi masih satuan decimal, untuk itu kita harus mengubah satuan tersebut menjadi satuan waktu, untuk itu di gunakan rumus :
Tabel 2 Kedatangan

\begin{tabular}{|c|c|c|c|}
\hline Kedatangan & $\begin{array}{c}\text { Acak } \\
\text { Rand0 }\end{array}$ & $\begin{array}{c}\text { Interval Waktu } \\
\text { Kedatangan }\end{array}$ & $\begin{array}{c}\text { Waktu } \\
\text { kedatangan }\end{array}$ \\
\hline 1 & 0 & $00: 00$ & $00: 00$ \\
\hline 2 & 0.7154 & $01: 45$ & $01: 45$ \\
\hline 3 & 0.4240 & $04: 28$ & $06: 13$ \\
\hline 4 & 0.3929 & $04: 52$ & $11: 05$ \\
\hline 5 & 0.4750 & $03: 53$ & $14: 58$ \\
\hline
\end{tabular}

2. Pelayanan

Setelah sebelumnya mendapatkan total kedatangan, maka dilanjutkan untuk membangkitkan waktu pelayanan menggunakan distribusi Eksponensial dengan

$-\frac{1}{\mu} \cdot \log (U)$, misalnya total kedatangan $\lambda=$ 5 dan $\mu=10$.

\section{Nasabah 1 :}

Waktu mulai $=$ waktu kedatangan $=0$

Bangkitkan $U=U(0,1) \quad=0,2938$

Waktu Layanan $=-\frac{1}{10} \cdot \log (0,2938)=$

0,0532

Selesai layanan $=0+0,0532=0,0532$

Waktu tunggu antrian $=0$

Waktu tunggu sistem $=0,0532$

Nasabah 2 :

Jika waktu kedatangan $\leq$ selesai layanan nasabah sebelumnya :

Waktu mulai $=$ selesai layanan nasabah sebelumnya

Jika waktu kedatangan > selesai layanan nasabah sebelumnya :

Waktu mulai $=$ waktu kedatangan

Waktu kedatangan $=0,0291<0,0532$, maka waktu mulai $=0,0532$

Bangkitkan $U=U(0,1)=0,0100$

Waktu Layanan $=-\frac{1}{10} \cdot \log (0,0100)=$ 0,2000

- Selesai layanan $=0,0532+0,2000=$ 0,2532

$\mathrm{x}=$ selesai layanan $* 3600=$ 912

Menit $=\mathrm{x} / 60=15.2=15$ menit 
Detik $=\mathrm{x} \bmod 60=12=12$ detik

- Waktu tunggu antrian $=0,0532$ $0,0291=0.0241$

$\mathrm{x}=$ Waktu tunggu antrian * $3600=87$

Menit $=\mathrm{x} / 60=1.45=1$ menit

Detik $=x \bmod 60=27=27$ detik

- Waktu tunggu sistem $=0,2532-$ $0,0291=0,2241$

$\mathrm{x}=$ Waktu tunggu antrian $*$ $3600=807$

Menit $=\mathrm{x} / 60=13.45=13$ menit

Detik $=x \bmod 60=27=27$ detik

Tabel 3. Pelayanan

\begin{tabular}{|c|c|c|c|c|c|c|c|}
\hline Nasabah & $\begin{array}{c}\text { Waktu } \\
\text { Kedatangan }\end{array}$ & $\begin{array}{c}\text { Waktu } \\
\text { Mulai }\end{array}$ & acak & $\begin{array}{c}\text { Waktu } \\
\text { Layanan }\end{array}$ & $\begin{array}{c}\text { Selesai } \\
\text { Layanan }\end{array}$ & $\begin{array}{c}\text { Waktu } \\
\text { tunggu } \\
\text { antrian }\end{array}$ & $\begin{array}{c}\text { Waktu } \\
\text { tumggu } \\
\text { sistem }\end{array}$ \\
\hline 1 & 0 & 0 & 0.2938 & 0.0532 & 0.0532 & 0.0000 & 0.0532 \\
\hline 2 & 0.0291 & 0.0532 & 0.0100 & 0.2000 & 0.2532 & 0.0241 & 0.2241 \\
\hline 3 & 0.1035 & 0.2532 & 0.6490 & 0.0188 & 0.2720 & 0.1496 & 0.3684 \\
\hline 4 & 0.1848 & 0.2720 & 0.4225 & 0.0374 & 0.3094 & 0.0872 & 0.1246 \\
\hline 5 & 0.2494 & 0.3094 & 0.020 & 0.0991 & 0.4085 & 0.0600 & 0.1591 \\
\hline
\end{tabular}

Tabel 4. Pelayanan dalam satuan waktu

\begin{tabular}{|c|c|c|c|c|c|c|c|}
\hline Nasahah & $\begin{array}{c}\text { Waktu } \\
\text { Kedatangan } \\
\text { (mum: dd) }\end{array}$ & $\begin{array}{l}\text { Waktu } \\
\text { Mulai } \\
\text { (nm : } \\
\text { dd) }\end{array}$ & acak & $\begin{array}{l}\text { Waktu } \\
\text { Layanan } \\
\text { (mim: } \\
\text { dd) }\end{array}$ & $\begin{array}{l}\text { Selesai } \\
\text { Layamas } \\
\text { (an :dd) }\end{array}$ & $\begin{array}{l}\text { Waktu } \\
\text { tunggu } \\
\text { antrian } \\
\text { (mmzdd) }\end{array}$ & $\begin{array}{l}\text { Wakte } \\
\text { tunggu } \\
\text { sistem }\end{array}$ \\
\hline 1 & $00=00$ & $00: \infty 0$ & 0.2938 & $03: 12$ & $03: 12$ & $00=00$ & $03: 12$ \\
\hline 2 & $01: 45$ & $03: 12$ & 0.0100 & $12: 00$ & $15: 12$ & $01: 27$ & $13: 27$ \\
\hline 3 & $05: 13$ & 12 & 0.6490 & $01: 08$ & $16: 19$ & $08: 58$ & $10: 06$ \\
\hline 4 & $11: 05$ & $16: 19$ & 0.4225 & $02: 15$ & $18: 34$ & $05: 14$ & $07: 29$ \\
\hline 5 & $14: 58$ & $18: 34$ & 0.1020 & $05: 57$ & $24: 31$ & $03: 36$ & $09: 33$ \\
\hline
\end{tabular}

Tabel 5. Hasil Simulasi

\begin{tabular}{|c|c|c|c|c|c|}
\hline Illasil & $\begin{array}{c}\mathrm{W}_{4} \\
\text { (2)aituTy }\end{array}$ & 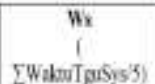 & $\begin{array}{c}\text { Lq } \\
\text { (2) Whatatgut }\end{array}$ & 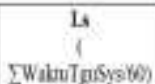 & 8 \\
\hline & 0.0642 & 0.1464 & 0.0053 & 0.0122 & 0.0148 \\
\hline
\end{tabular}

Tabel 6. Data rata-rata kedatangan $(\lambda)$ dan pelayanan $(\boldsymbol{\mu})$

\begin{tabular}{|l|c|c|c|c|c|c|c|c|c|c|}
\hline \multirow{2}{*}{ waktu } & \multicolumn{2}{|c|}{$\mathrm{h} 1$} & \multicolumn{2}{c|}{$\mathrm{h} 2$} & \multicolumn{2}{c|}{$\mathrm{h} 3$} & \multicolumn{2}{c|}{$\mathrm{h} 4$} & \multicolumn{2}{c|}{$\mathrm{h} 5$} \\
\cline { 2 - 11 } & $\lambda$ & $\mu$ & $\lambda$ & $\mu$ & $\lambda$ & $\mu$ & $\lambda$ & $\mu$ & $\lambda$ & $\mu$ \\
\hline $08.00-$ & & & & & & & & & & \\
09.00 & 13 & 9 & 7 & 7 & 7 & 6 & 4 & 2 & 7 & 4 \\
\hline $\begin{array}{l}09.00- \\
10.00\end{array}$ & 12 & 8 & 12 & 12 & 4 & 6 & 9 & 9 & 13 & 9 \\
\hline
\end{tabular}

$\lambda$

$=\frac{(13+7+7+4+7+12+12+4+9+13)}{10}$

$=8,8=9$ (dibulatkan)

$\mu_{1}$

$=\frac{(9+7+6+2+4+8+12+6+9+9)}{10}$

$=7,2=7$

Dari kesimpulan dengan menggunakan $\lambda=5$ dan $\mu=10$, di dapatkan hasil simulasi pada tabel III.5 dengan kesimpulan :

- $\rho \quad=0.0148 \times 100 \%=1.48 \%$

- $\mathrm{Wq}=0.0642$

$\mathrm{X}=\mathrm{Wq} * 3600=231.12$

Menit $=\mathrm{x} / 60=3.852=3$ Menit

Detik $=\mathrm{x}$ Mod $60=51.12=51$ Detik

- $\mathrm{Ws}=0.1464$

$\mathrm{x}=\mathrm{Wq} * 3600=527.04$

Menit $=\mathrm{x} / 60=8.784=8$ Menit

Detik $=\mathrm{x}$ Mod $60=47.04=47$ Detik

Dapat dilihat bahwa probabilitas server sibuk adalah $1.48 \%$ dengan rata-rata waktu tunggu dalam antrian 0.0642 atau 3 menit 51 detik dan rata- rata waktu tunggu dalam sistem 0.1464 atau 8 menit 47 detik.

\section{KESIMPULAN}

\section{Kesimpulan}

Dengan melakukan simulasi dari data diatas di dapatkan hasil sebagai berikut :

Simulasi dilakukan pertama kali dengan durasi simulasi 5 jam dan jumlah server yang melayani pelanggan adalah 4 server, maka Berdasarkan hasil pembahasan dan pengujian simulasi didapatkan kesimpulansebagai berikut: 
Hasil simulasi Eksponensial, dengan parameter $\lambda=9, \mu=7$

1. Jika dilayani dengan 1 server maka ratarata server sibuk (utilityserver) $129.89 \%$, rata-rata waktu tunggu (Wq) 59 menit 25 detik, rata-rata waktu tunggu dalam sistem (Ws) 1 Jam 7 menit 32 detik, dan rata-rata jumlah pelanggan dalam sistem (Lq) 9.5067, rata-rata jumlah pelanggan dalam antrian (Ls) 10.8057 rata-rata waktu tunggu masih sangat lama akan menyebabkan nasabah bosan dan pergi.

2. Jika dilayani dengan 2 server maka ratarata server sibuk (utilityserver) $87.6 \%$, rata-rata waktu tunggu (Wq) 19 menit 05 detik, rata-rata waktu tunggu dalam sistem (Ws) 30 menit 02 detik, dan ratarata jumlah pelanggan dalam sistem (Lq) 3.0529 , rata-rata jumlah pelanggan dalam antrian (Ls) 4.8049 rata-rata server sibuk lebih kecil namun rata rata waktu tunggu masih lama dan menyebabkan masih terjadinya antrian.

3. Jika dilayani dengan 3 server maka ratarata server sibuk (utilityserver) $53.01 \%$, rata-rata waktu tunggu (Wq) 32 detik, rata-rata waktu tunggu dalam sistem (Ws) 10 menit 31 detik, dan rata-rata jumlah pelanggan. dalam sistem (Lq) 0.0935, rata-rata jumlah pelanggan dalam antrian (Ls) 1.6837, dengan menggunakan 3 server didapatkan probabilitas server sibuk yang mendekati $50 \%$ yang artinya, jumlah waktu tunggu tidak terlalu lama dan tidak membuat antrian panjang.

4. Jika dilayani dengan 4 server maka ratarata server sibuk (utilityserver) $27.5 \%$, rata-rata waktu tunggu $(\mathrm{Wq}) 0$, rata-rata waktu tunggu dalam sistem (Ws) 6 menit 53 detik, dan rata-rata jumlah pelanggan. dalam sistem $\left(\mathrm{L}_{\mathrm{q}}\right)$ 0, rata-rata jumlah pelanggan dalam antrian (Ls) 1.1001, dengan 4 server di dapatkan antrian tidak terjadi dan menyebabkan banyaknya server yang menganggur.

Dari hasil simulasi jumlah server yang terbaik adalah 3 server.

\section{Saran}

Simulasi yang dilakukan pada penelitian ini adalah simulasi antrian denganpola kedatangan tunggal, untuk dapat menganalisa performansi antrian. Untukpenelitian selanjutnya diharapkan dapat dikembangkan simulasi antrian yang memilikikedatangan atau pelayanan dengan distribusi yang lain dan dapat digunakan sebagaiacuan dalam mengambil keputusan agar dapat memaksimalkan waktu pelayananterhadap pelanggan atau menambah jumlah server sebagai pelayan, danmeminimumkan server jika dianggap berlebihan dalam suatu pelayanan agar dapatmemperkecil biaya operasional.

\section{DAFTAR PUSTAKA}

[1] A. M. H. Pardede, H. Mawengkang, and Z. Situmorang, "SIMULASI ANTRIAN KEDATANGAN BERKELOMPOK DENGAN PELAYANAN WEIBULL OLEH BANYAK SERVER," J. Teknol. Inf. dan Komun., vol. 3, no. 1, pp. 1-10, 2014.

[2] A. M. H. Pardede, "SIMULASI ANTRIAN PELAYANAN NASABAH BANK MENGGUNAKAN METODE HYPEREXPONENTIAL," J. Inf. Syst. Dev., vol. 3, no. 1, pp. 33-43, 2018.

[3] Al-Bahra, "Analisis dan Desain Sistem Informasi," Pengertian Komputer, Definisi Komputer dan Perancangan, 2005.

[4] R. J. Simamora, "Simulasi Antrian Multiple Server Dengan Pola Kedatangan Berkelompok," Tesis, Program Pasca Sarjana Ilmu Komputer, Universitas Gadjah Mada, Yogyakarta., 2010.

[5] A. M. H. Pardede, "Simulasi Antrian Pelayanan Berkelompok Oleh Banyak Server." (Master's Thesis), Universitas Sumatera Utara, Medan. 